\title{
IMPLEMENTATION OF WORKSHOP ACTIVITIES TO IMPROVE TEACHER COMPETENCY IN DEVELOPING LESSON PLANS
}

\author{
Sargiono \\ SDN 017 Candirejo Kec. Pasir Penyu \\ Sargiono006@gmail.com
}

\begin{abstract}
This research was conducted at SDN 017 Candirejo, Pasir Penyu District with 15 teachers. This study aims to improve teacher competency in Developing Lesson Plans (RPP) by implementing workshop activities. The type of the research was action research. This research procedure was carried out in two cycles, and the steps in each cycle consisted of planning, implementing actions, observing, and reflecting. The results showed that before giving an average action, the teacher got a value of 74.4 with sufficient qualifications, then after taking action in the first cycle, the average teacher got a score of 81 with good qualifications. In the second cycle, the average teacher's assessment increased to 86.7 with very good qualifications. The percentage increased from the pre-action to the first cycle was $6.6 \%$ and the pre-action to the second cycle was $12.3 \%$. It can be concluded that the implementation of the workshop activities can improve teacher competency in preparing RPP at SDN 017 Candirejo, Pasir Penyu District.
\end{abstract}

Keywords: teacher competency, lesson plans, workshop

\section{PELAKSANAAN KEGIATAN WORKSHOP DALAM UPAYA MENINGKATKAN KOMPETENSI GURU DALAM MENYUSUN RENCANA PELAKSANAAN PEMBELAJARAN}

\begin{abstract}
ABSTRAK
Penelitian ini dilakukan di SDN 017 Candirejo Kecamatan Pasir Penyu dengan jumlah guru sebanyak 15 orang. Penelitian ini bertujuan untuk meningkatkan kompetensi guru dalam menyusun Rencana Pelaksanaan Pemebelajaran (RPP) dengan menerapkan pelaksanaan kegiatan workshop. Jenis penelitian ini merupakan penelitian tindakan. Prosedur penelitian ini dilaksanakan dalam dua siklus, dan langkah-langkah dalam setiap siklus terdiri dari perencanaan, pelaksanaan tindakan, observasi, dan refleksi. Hasil penelitian menunjukan, sebelum pemberian tindakan rata-rata guru mendapat nilai sebesar 74.4 dengan kualifikasi cukup, setelah dilakukan tindakan pada siklus I rata-rata guru mendapat nilai sebesar 81 dengan kualifikasi baik, dan pada siklus II rata-rata penilaian guru meningkat menjadi 86.7 dengan kualifikasi amat baik. Peningkatan persentase dari sebelum tindakan ke siklus I sebesar 6.6\% dan sebelum tindakan ke siklus II sebesar 12.3\%. dapat disimpulkan bahwa pelaksanaan kegiatan workshop dapat meningkatkan kompetensi guru dalam menyusun RPP di SDN 017 Candirejo Kecamatan Pasir Penyu.
\end{abstract}

Kata Kunci: kompetensi guru, RPP, workshop

\begin{tabular}{|c|c|c|}
\hline Submitted & Accepted & Published \\
\hline 01 Maret 2020 & 13 Mei 2020 & 28 Mei 2020 \\
\hline
\end{tabular}

\begin{tabular}{|l|l|l|l|l} 
Citation & $:$ & Sargiono. (2020). Implementation Of Workshop Activities To Improve Teacher Competency In Developing Lesson \\
\hline
\end{tabular} Plans. Jurnal PAJAR (Pendidikan dan Pengajaran), 4(3), 586-596. DOI : http://dx.doi.org/10.33578/pjr.v4i2.8014.

\section{PENDAHULUAN}

Kompetensi merupakan kebulatan penguasaan pengetahuan, keterampilan, dan sikap yang ditampilkan melalui unjuk kerja. Kepmendiknas No. 045/U/2002 menyebutkan kompetensi sebagai seperangkat tindakan cerdas dan penuh tanggung jawab dalam melaksanakan tugas-tugas sesuai dengan pekerjaan tertentu. Jadi kompetensi guru dapat dimaknai sebagai kebulatan pengetahuan, keterampilan dan sikap yang berwujud tindakan cerdas dan penuh tanggung jawab dalam melaksanakan tugas sebagai agen pembelajaran. 
Selain itu, guru harus memahami dengan baik tindakan yang harus dilakukannya dalam melaksanakan tugas dan tanggung jawabnya sebagai guru di bidang pendidikan. Ada tiga tugas utama yang harus dilakukan oleh guru, yakni (a) merencanakan pembelajaran, (b) melaksanakan pembelajaran, dan (c) menilai pembelajaran. Ketiga tugas utama yang harus dilakukan guru tersebut, perencanaan pembelajaran memiliki peranan yang sangat penting karena pelaksanaan dan penilaian pembelajaran dapat terlaksana dengan baik jika guru mampu membuat perencanaan pembelajaran dengan baik (Rambe, 2019).

Untuk mampu melaksanaakan tugas mengajar dengan baik, guru harus memiliki kemampuan profesional, yaitu terpenuhinya sepuluh kompetensi guru, yang meliputi (1) menguasai bahan; (2) mengelola program belajar mengajar; (3) mengelola kelas; (4) penggunaan media atau sumber; (5) menguasai landasanlandasan pendidikan; (6) mengelola interaksi belajar mengajar; (7) menilai prestasi siswa untuk kepentingan pelajaran; (8) mengenal fungsi layanan bimbingan dan penyuluhan di sekolah; (9) mengenal dan menyelenggarakan administrasi sekolah, dan (10) memahami prinsip-prinsip dan menafsirkan hasil penelitian pendidikan guna keperluan pengajaran. Dari beberapa pendapat di atas, maka dapat kita ketahui bahwa betapa pentingnya perencanaan pembelajaran itu, dimana

\section{METODE PENELITIAN}

Penelitian ini dilaksanakan di SDN 017 Candirejo Kec. Pasir Penyu. Subjek penelitian ini merupakan semua guru yang berjumlah sebanyak 15 orang terdiri dari guru kelas dan guru mata pelajaran seperti Agama dan Penjasorkes (Pendidikan Jasmani, Olahraga dan Kesehatan).

Penelitian ini merupakan penelitian tindakan (action research) yang bertujuan untuk meningkatkan kemampuan guru dalam menyusun rencana pelaksanaan pembelajaran (RPP) dengan melakukan workshop. Prosedur penelitian ini dilaksanakan dalam dua siklus, dan langkahlangkah dalam setiap siklus terdiri dari perencanaan, pelaksnaan tindakan, observasi, dan semuanya terintegrasi di dalam sebuah rencana pelaksanaan pembelajaran yang dibuat oleh guru (Sardiman dalam Maimunah, 2019).

Kenyataanya, berdasarkan observasi peneliti masih ada guru dalam merancang RPP terkesan asal-asalan dan tidak jarang juga guru hanya meng kopy paste dari internet atau merubah tahun RPP yang telah ada. Ini semua menunjukan bahwa masih kurangnya kompetensi guru dalam Menyusun RPP yang baik dalam mendukung proses pembelajaran di SDN 017 Candirejo Kecamatan Pasir Penyu.

Dalam rangka mengatasi permasalahan yang peneliti temui di atas, peneliti berinisiatif melaksanakan kegiatan workshop dalam rangka meningkatkan kompetensi guru dalam menyusun RPP di SDN 017 Candirejo. Menurut Nurzali (dalam Rinawati, 2019) workshop adalah bantuan profesional yang diberikan pengawas/ kepala sekolah kepada guru, melalui siklus perencanaan yang sistematis, koordinasi yang bagus sehingga mampu menghasilkan produk kinerja yang dapat memperbaiki kinerja guru. Lebih lanjut, Badudu (dalam Gusmarni, 2019) mengatakan workshop merupakan suatu pertemuan ilmiah dalam bidang pendidikan untuk menghasilkan karya nyata. Makadari itu, tujuan dari penelitian ini adalah untuk meningkatkan kompetensi guru dalam menyusun RPP dengan melaksanakan kegiatan workshop di SDN 017 Candirejo.

refleksi. Secara rinci prosedur penelitian mengikuti langkah-langkah sebagai berikut:

\section{Siklus I \\ 1. Perencanaan}

Pada kegiatan awal yaitu perencanaan ada beberapa kegiatan yang harus dilakukan, Adapun kegiatan tersebut dapat dilihat sebagai berikut: 1) peneliti mengumpulkan guru melalui rapat bulanan majelis guru yang peneliti pimpin sendiri; 2) melakukan penyusunan jadwal workshop seperti menentukan hari pelaksanaan, tanggal pelaksanaan, jam pelaksanaan dan tempat (ruang) pelaksanaan; 3) peneliti menyiapkan materi 
workshop yang akan di lakukan yaitu bagaimana Langkah-langkah Menyusun RPP yang baik dan benar; 4) peneliti meminta guru membawa perlengkapan seperti; kurikulum, silabus, RPP yang telah dirumuskan guru, leptop dan buku referensi (jika ada); 5) peneliti membentuk kelompok guru berdasarkan kelas dan bidang pelajaran yang diampuh seperti guru Agama dan Penjasorkes; 6) Menyiapkan konsumsi peserta untuk workshop.

\section{Pelaksanaan}

Pada tahap ini peneliti melaksanakan rencana tindakan yaitu melaksanakan workshop di SDN 017 Candirejo, pelaksanaan tersebut berupa penjelassan teknis dan pemaparan RPP yang baik dan benar menurut permendiknas; setelah pemaparan materi selesai dilakukan tanya jawab, diskusi (Menyusun RPP sesuai dengan kelompok yang telah dibagi), mempresentasikan hasil penyusunan RPP, dan melakukan revisi.

\section{Observasi}

Pada tahap ini peneliti melakukan kegiatan observasi terhadap seluruh kegiatan yang dilaksanakan seperti: melihat kesiapan fisik dan psikis guru, kesiapan RPP, kehadiran guru, kesiapan alat pendukung workshop yang dibawa guru.

\section{Refleksi}

Pada tahap refleksi, peneliti melakukan evaluasi terhadap tindakan dan data-data yang diperoleh. Kemudian dilanjutkan dengan penyusunan langkah-langkah untuk siklus kedua. Indikator Keberhasilan dalam penelitian ini adalah sebagai berikut:

1) proses pelaksanaan workshop, guru minimal:

a. Siap secara fisik dan fisikis guru $=85 \%$

b. Kesiapan RPP $=85 \%$

c. Kehadiran guru $=90 \%$

d. Kesiapan alat pendukung $=70 \%$

\section{Siklus II}

Pada dasarnya siklus II memiliki prosedur yang sama dengan siklus I, hanya saja diadakan perbaikan pada hal-hal yang dilihat ada kelemahan serta mempertahankan hal-hal yang sudah berjalan dengan baik. Tidak menutup kemungkinan juga dilakukan modifikasi terhadap hal-hal sudah baik supaya tindakan yang diberikan tidak membosankan.

\section{Analisis Data}

Data yang telah diperoleh berdasarkan pelaksanaan siklus di atas akan dianalisis dengan menggunakan rumus dan deskripsi kualifikasi hasil sebagai berikut:

$$
\begin{array}{ll}
\mathrm{P}=\frac{S}{N} \times 100 \\
\mathrm{P} & =\text { Nilai akhir } \\
\mathrm{S} & =\text { Jumlah skor penilaian } \\
\mathrm{N} & =\text { Skor maksimal }
\end{array}
$$

Tabel 1. Interval dan Kualifikasi Penilaian

\begin{tabular}{cc}
\hline Interval & Kualifikasi \\
\hline $86-100$ & Amat Baik \\
$76-85$ & Baik \\
$60-75$ & Cukup \\
$50-59$ & Kurang \\
$0-49$ & Sangat Kurang \\
\hline
\end{tabular}

(Adaptasi dari Baharuddin, 2019)

Hasil analisis terhadap pelaksanaan workshop dalam meningkatkan kompetensi guru menyusun RPP dapat dikatakan berhasil apabila guru setelah dilakukan observasi dan penilaian terhadap penyususn model pembelajaran mendapatkan nilai $\geq 76$ atau minimal berada pada kategori baik. Ini berarti pelaksanaan workshop dapat meningkatkan kompetensi guru dalam menyusun RPP di SDN 017 Candirejo. 


\section{HASIL DAN PEMBAHASAN}

Pada siklus I dan II, peneliti mengidentifikasi kemampuan awal 15 orang guru yang menjadi subjek penelitian melalui observasi menggunakan lembar pengamatan. Selain itu dilakukan pula identifikasi kesiapan guru mengikuti workshop dalam menyusun RPP. Hasil analisis penilaian guru dalam kesiapan pelaksanaan wokshop, hasil penilaian sebelum tindakan dan sesudah tindakan pada siklus I dan II dapat dilihat pada table 2 di bawah ini:

Tabel 2. Hasil Observasi Pelaksanaan Workshop Pada Siklus I

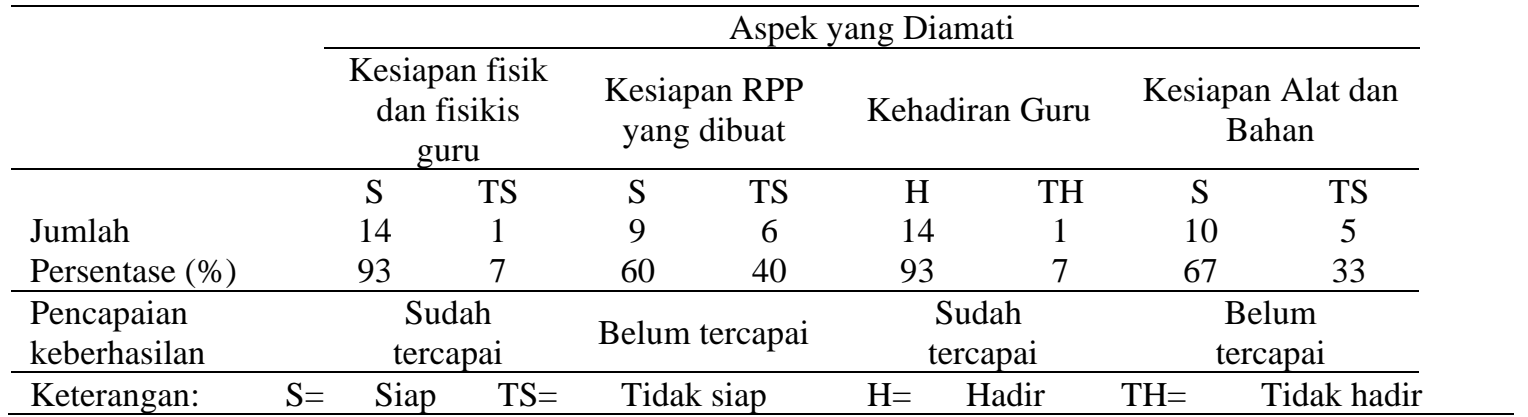

Berdasarkan tabel 2 di atas, hasil observasi pelaksaan workshop siklus I menunjukkan bahwa pada aspek kesiapan fisik dan mental; sebanyak 14 (93\%) orang guru telah siap dan $1(7 \%)$ guru tidak siap, pada aspek kesiapan RPP yang dibuat; sebanyak 9 (60\%) guru telah siap dan 6 (40\%) guru tidak siap, pada aspek kehadiran guru; sebanyak 14 (93\%) guru hadir menikuti workshop dan hanya $1(7 \%)$ guru tidak hadir, dan pada aspek kesiapan alat dan bahan dalam mengikuti workshop; sebanyak 10 (67\%) guru telah siap dan 5 (33\%) guru belum siap. Berdasarkan dekripsi ini tampaknya kesiapan guru dalam mengikuti worksop pada siklus I belum memenuhi kriteria keberhasilan untuk semua aspek yang diharapkan. Untuk itu perlu dilanjutkan kepelaksanaan siklus II. Hasil observasi siklus II dapat dilihat pada table 3 di bawah ini:

Tabel 3. Hasil Observasi Pelaksanaan Workshop Pada Siklus II

\begin{tabular}{|c|c|c|c|c|c|c|c|c|}
\hline & \multicolumn{8}{|c|}{ Aspek yang Diamati } \\
\hline & \multicolumn{2}{|c|}{$\begin{array}{c}\text { Kesiapan fisik } \\
\text { dan fisikis } \\
\text { guru }\end{array}$} & \multicolumn{2}{|c|}{$\begin{array}{l}\text { Kesiapan RPP } \\
\text { yang dibuat }\end{array}$} & \multicolumn{2}{|c|}{ Kehadiran Guru } & \multicolumn{2}{|c|}{$\begin{array}{c}\text { Kesiapan Alat dan } \\
\text { Bahan }\end{array}$} \\
\hline & $\mathrm{S}$ & TS & $\mathrm{S}$ & TS & $\mathrm{H}$ & $\mathrm{TH}$ & $\mathrm{S}$ & TS \\
\hline Jumlah & 15 & 0 & 13 & 2 & 15 & 0 & 14 & 1 \\
\hline Persentase $(\%)$ & 100 & 0 & 87 & 13 & 100 & 0 & 93 & 7 \\
\hline $\begin{array}{l}\text { Pencapaian } \\
\text { keberhasilan }\end{array}$ & \multicolumn{2}{|c|}{$\begin{array}{c}\text { Sudah } \\
\text { tercapai }\end{array}$} & \multirow{2}{*}{\multicolumn{2}{|c|}{$\begin{array}{c}\text { Sudah } \\
\text { tercapai }\end{array}$}} & \multicolumn{2}{|c|}{$\begin{array}{l}\text { Sudah } \\
\text { tercapai }\end{array}$} & \multirow{2}{*}{\multicolumn{2}{|c|}{$\begin{array}{c}\text { Sudah } \\
\text { tercapai }\end{array}$}} \\
\hline angan: $\quad \mathrm{S}=$ & iap & & & & Hadi & $\mathrm{TH}=$ & & \\
\hline
\end{tabular}

Berdasarkan tabel 2 di atas, hasil observasi pelaksaan workshop siklus II menunjukkan bahwa pada aspek kesiapan fisik dan mental; sebanyak 15 (100\%) orang guru telah siap, pada aspek kesiapan RPP yang dibuat; sebanyak $13(87 \%)$ guru telah siap dan hanya 2 $(13 \%)$ guru tidak siap, pada aspek kehadiran guru; sebanyak $15(100 \%)$ guru hadir menikuti workshop, dan pada aspek kesiapan alat dan bahan dalam mengikuti workshop; sebanyak 14 (93\%) 
guru telah siap dan hanya 1 (7\%) guru belum siap. Berdasarkan hasil observasi yang dilakukan ini tampaknya kesiapan guru dalam mengikuti worksop telah memenuhi kriteria keberhasilan untuk semua aspek. Namun belum sepenuhnya tercapai seratus persen.

Untuk penilaian kompetensi guru sebelum kegiatan workshop dapat dilihat pada table 4 di bawah:

Tabel 4. Hasil Penilaian Komptensi Guru Sebelum Kegiatan Workshop

\begin{tabular}{lcc}
\hline \multicolumn{1}{c}{ Indikator yang Dinilai } & Nilai \% & Kualifikasi \\
\hline Kompetensi Inti & 86.3 & Baik \\
Kompetensi Dasar dan Indikator & 81.6 & Baik \\
Tujuan Pembelajaran & 68.6 & Cukup \\
Materi dan Metode Pembelajaran & 67.6 & Cukup \\
Langkah-Langkah Pembelajaran/ & 70.8 & Cukup \\
Kegiatan pembelajaran & & \\
$\begin{array}{l}\text { Media Alat dan Sumber Pembelajaran } \\
\text { Penilaian/Evaluasi }\end{array}$ & 72.8 & Cukup \\
\multicolumn{1}{c}{ Rata-rata } & 73.1 & Cukup \\
\end{tabular}

Dari table 4 di atas diketahui hasil penilaian kompetensi guru sebelum kegiatan workshop berada pada kualifikasi cukup dan baik. Pada indikator kompetensi inti guru memperoleh nilai $86.3 \%$ dengan kualifikasi baik. Indikatoru kompetensi dasar dan indikator guru memperoleh nilai $81.6 \%$ dengan kualifikasi baik. Indikator tujuan pembelajaran guru mendapat nilai $68.6 \%$ kualifikasi cukup. Indikator materi dan metode pembelajaran guru mendapat nilai $67.6 \%$ kualifikasi cukup. Indikator Langkah-langkah pembelajaran/ kegiatan inti guru mendapat nilai cukup. Indikator media alat dan sumber belajar guru mendapat nilai 72.8 kualifikasi cukup, dan indikator penilaian/ evaluasi guru mendapat nilai $74.4 \%$ kualifikasi cukup.

Selanjutnya dilihat dari kompetensi guru dalam menyusun RPP melalui pemberian kegiatan workshop, hasil penilaian terjadi peningkatan dari sebelum diberikan tindakan ke siklus I dan siklus II. Hasil dari penilaian kompetensi guru dalam menyusunan RPP 15 orang guru dapat dilihat pada table 5 di bawah ini:

Tabel 5. Hasil Penilaian Komptensi Guru dalam Menyusun RPP melalui Kegiatan Workshop pada Siklus I dan II

\begin{tabular}{clcccc}
\hline No & Nama guru & $\begin{array}{c}\text { Mengajar kelas/ } \\
\text { Mata Pelajaran }\end{array}$ & $\begin{array}{c}\text { Indikator yang } \\
\text { Dinilai }\end{array}$ & \multicolumn{2}{c}{ Nilai \% } \\
Siklus I & Siklus II \\
\hline 1. & Guru 1 & Kelas I & & 93 & 93 \\
2. & Guru 2 & Kelas I & & 95 & 95 \\
3. & Guru 3 & Kelas II & Kelas II & 83 & 87 \\
4. & Guru 4 & Kelas III & & 90 & 90 \\
5. & Guru 5 & Kelas III & & 87 & 90 \\
6. & Guru 6 & Kelas IV & Kompetensi Inti & 90 & 93 \\
7. & Guru 7 & Kelas IV & & 99 & 89 \\
8. & Guru 8 & Kelas V & & 88 & 93 \\
9. & Guru 9 & Kelas V & & 73 & 88 \\
10 & Guru 10 & Kelas VI & & 93 & 93 \\
11 & Guru 11 & Agama & & 93 & 93 \\
12 & Guru 12 & Agama & 88 & 90 \\
13 & Guru 13 & Penjasorkes & & 87 & 88 \\
14 & Guru 14 & Penjasorkes & & 77 & 90 \\
15 & Guru 15 & Rata-rata & & 87.9 & 90.1 \\
& & Kualifikasi & & Amat Baik & Amat Baik \\
\hline
\end{tabular}


Berdasarkan table 5 di atas, dapat kita ketahui bahwa kompetensi guru dalam merumuskan kompetensi inti pada RPP yang mereka buat telah berada pada kualifikasi amat baik, dengan nilai rata-rata pada siklus I sebesar
87.9 dan siklus II sebesar 90.1. ini membuktikan tidak ada guru yang tidak mencantumkan kompetendi inti pada RRP yang mereka buat. Sedangkan untuk penilaian kompetendi dasar dan indikator dapat dilihat pada table 6 di bawah ini:

\section{Tabel 6. Hasil Penilaian Komptensi Guru dalam Menyusun RPP melalui Kegiatan Workshop pada Siklus I dan II}

\begin{tabular}{clcccc}
\hline No & Nama guru & Mengajar kelas/ & Indikator yang & \multicolumn{2}{c}{ Nilai \% } \\
& Mata Pelajaran & Dinilai & Siklus I & Siklus II \\
\hline 1. & Guru 1 & Kelas I & & 83 & 99 \\
2. & Guru 2 & Kelas I & & 93 & 93 \\
3. & Guru 3 & Kelas II & & 83 & 90 \\
4. & Guru 4 & Kelas II & & 88 & 90 \\
5. & Guru 5 & Kelas III & & 73 & 77 \\
6. & Guru 6 & Kelas III & & 93 & 93 \\
7. & Guru 7 & Kelas IV & Kompetensi Dasar & 90 & 90 \\
8. & Guru 8 & Kelas IV & dan Indikator & 88 & 88 \\
9. & Guru 9 & Kelas V & & 77 & 90 \\
10 & Guru 10 & Kelas V & & 88 & 93 \\
11 & Guru 11 & Kelas VI & & 90 & 90 \\
12 & Guru 12 & Agama & & 73 & 77 \\
13 & Guru 13 & Agama & & 90 & 90 \\
14 & Guru 14 & Penjasorkes & & 77 & 77 \\
15 & Guru 15 & Penjasorkes & & 84.6 & 87.8 \\
& & Rata-rata & & Baik & Amat \\
& & Kualifikasi & & & Baik \\
\hline
\end{tabular}

Berdasarkan table 6 di atas, dapat kita ketahui bahwa kompetensi guru dalam merumuskan kompetensi dasar dan indikator pada RPP yang mereka buat telah berada pada kualifikasi baik dan amat baik. Peningkatan ini terjadi karena guru telah memahami bagaimana cara merumuskan dengan baik kompetensi dasar dan indikator pada RPP yang mereka buat melalui kegiatan workshop, hal ini dibuktikan oleh nilai rata-rata guru pada siklus I sebesar 84.6 dan 87.8 pada siklus II. Sedangkan hasil penilaian kompetensi guru dalam merumuskan tujuan pembelajaran pada RPP yang mereka buat dapat dilihat pada table 7 di bawah ini:

Tabel 7. Hasil Penilaian Komptensi Guru dalam Menyusun RPP melalui Kegiatan Workshop pada Siklus I dan II

\begin{tabular}{clcccc}
\hline No & Nama guru & $\begin{array}{c}\text { Mengajar kelas/ } \\
\text { Mata Pelajaran }\end{array}$ & $\begin{array}{c}\text { Indikator yang } \\
\text { Dinilai }\end{array}$ & \multicolumn{2}{c}{ Nilai \% } \\
Siklus I & Siklus II \\
\hline 1. & Guru 1 & Kelas I & & 73 & 83 \\
2. & Guru 2 & Kelas I & & 70 & 80 \\
3. & Guru 3 & Kelas II & Tujuan & 73 & 73 \\
4. & Guru 4 & Kelas II & Pembelajaran & 77 & 80 \\
5. & Guru 5 & Kelas III & & 73 & 75 \\
6. & Guru 6 & Kelas III & & 70 & 77 \\
7. & Guru 7 & Kelas IV & & 80 & 88 \\
8. & Guru 8 & Kelas IV & & & \\
\hline
\end{tabular}




\begin{tabular}{clccc}
\hline 9. & Guru 9 & Kelas V & 88 & 93 \\
10 & Guru 10 & Kelas V & 73 & 88 \\
11 & Guru 11 & Kelas VI & 70 & 93 \\
12 & Guru 12 & Agama & 65 & 88 \\
13 & Guru 13 & Agama & 75 & 83 \\
14 & Guru 14 & Penjasorkes & 75 & 80 \\
15 & Guru 15 & Penjasorkes & 70 & 93 \\
& & Rata-rata & 73.2 & 83.8 \\
& & Kualifikasi & Baik & Baik \\
\hline
\end{tabular}

Berdasarkan table 7 di atas, dapat kita ketahui bahwa kompetensi guru dalam merumuskan tujuan pembelajaran pada RPP yang mereka buat telah berada pada kualifikasi baik. Hal ini dibuktikan oleh pada siklus I rata-rata guru mendapat nilai sebesar 73.2 dan pada siklus II sebesar 83.8. untuk penilaia materi dan metode pembelajaran pada siklus I dan II dapat dilihat pada table 8 di bawah ini:

\section{Tabel 8. Hasil Penilaian Komptensi Guru dalam Menyusun RPP melalui Kegiatan Workshop} pada Siklus I dan II

\begin{tabular}{clcccc}
\hline No & Nama guru & Mengajar kelas/ & Indikator yang & \multicolumn{2}{c}{ Nilai \% } \\
& & Mata Pelajaran & Dinilai & Siklus I & Siklus II \\
\hline 1. & Guru 1 & Kelas I & & 75 & 93 \\
2. & Guru 2 & Kelas I & & 70 & 88 \\
3. & Guru 3 & Kelas II & & 73 & 93 \\
4. & Guru 4 & Kelas II & & 80 & 90 \\
5. & Guru 5 & Kelas III & & 88 & 90 \\
6. & Guru 6 & Kelas III & & 77 & 88 \\
7. & Guru 7 & Kelas IV & Materi dan Metode & 77 & 83 \\
8. & Guru 8 & Kelas IV & Pembelajaran & 83 & 93 \\
9. & Guru 9 & Kelas V & & 90 & 93 \\
10 & Guru 10 & Kelas V & & 88 & 90 \\
11 & Guru 11 & Kelas VI & & 70 & 88 \\
12 & Guru 12 & Agama & & 90 & 93 \\
13 & Guru 13 & Agama & & 83 & 90 \\
14 & Guru 14 & Penjasorkes & & 80 & 83 \\
15 & Guru 15 & Penjasorkes & & 88 & 90 \\
& & Rata-rata & & 80.8 & 89.6 \\
& & Kualifikasi & & Baik & Amat \\
& & & & Baik \\
\hline
\end{tabular}

Berdasarkan table 8 di atas, dapat kita ketahui bahwa kompetensi guru dalam merumuskan tujuan pembelajaran pada RPP yang mereka buat telah berada pada kualifikasi baikdan amat baik. Peningkatan ini dibuktikan oleh rata- rata guru pada siklus I mendapat nilai sebesar 80.8 dan pada siklus II mendapat nilai 89.6. Untuk penilaia Langkah-langkah pembelajaran/kegiatan pembelajaran pada siklus I dan II dapat dilihat pada table 9 di bawah ini: 
Tabel 9. Hasil Penilaian Komptensi Guru dalam Menyusun RPP melalui Kegiatan Workshop pada Siklus I dan II

\begin{tabular}{clcccc}
\hline No & Nama guru & $\begin{array}{c}\text { Mengajar kelas/ } \\
\text { Mata Pelajaran }\end{array}$ & $\begin{array}{c}\text { Indikator yang } \\
\text { Dinilai }\end{array}$ & \multicolumn{2}{c}{ Nilai \% } \\
& & Kelas I & & 75 & 80 \\
\hline 1. & Guru 1 & Kelas I & & 70 & 73 \\
2. & Guru 2 & Kelas II & & 65 & 77 \\
3. & Guru 3 & Kelas II & & 70 & 80 \\
4. & Guru 4 & Kelas III & & 77 & 73 \\
5. & Guru 5 & Kelas III & Langkah-Langkah & 73 & 80 \\
6. & Guru 6 & Kelas IV & Pembelajaran/ & 88 & 90 \\
7. & Guru 7 & Kelas IV & Kegiatan & 77 & 83 \\
8. & Guru 8 & Kelas V & pembelajaran & 90 & 93 \\
9. & Guru 9 & Kelas V & & 73 & 77 \\
10 & Guru 10 & Kelas VI & & 80 & 83 \\
11 & Guru 11 & Agama & & 80 & 88 \\
12 & Guru 12 & Agama & & 83 & 83 \\
13 & Guru 13 & Penjasorkes & & 85 & 88 \\
14 & Guru 14 & Penjasorkes & & 65 & 80 \\
15 & Guru 15 & Rata-rata & & 76.7 & 81.8 \\
& & Kualifikasi & & Baik & Baik \\
\hline
\end{tabular}

Berdasarkan table 9 di atas, dapat kita ketahui bahwa kompetensi guru dalam merumuskan Langkah-langkah pembelajaran/ kegiatan pembelajaran pada RPP yang mereka buat telah berada pada kualifikasi baik.
Peningkatan ini dibuktikan oleh rata-rata guru pada siklus I mendapat nilai sebesar 76.7 dan pada siklus II mendapat nilai 81.8 . Untuk penilaia media alat dan sumber pembelajaran pada siklus I dan II dapat dilihat pada table 10 di bawah ini:

Tabel 10. Hasil Penilaian Komptensi Guru dalam Menyusun RPP melalui Kegiatan Workshop pada Siklus I dan II

\begin{tabular}{|c|c|c|c|c|c|}
\hline \multirow[t]{2}{*}{ No } & \multirow[t]{2}{*}{ Nama guru } & \multirow{2}{*}{$\begin{array}{l}\text { Mengajar kelas/ } \\
\text { Mata Pelajaran }\end{array}$} & \multirow{2}{*}{$\begin{array}{c}\text { Indikator yang } \\
\text { Dinilai }\end{array}$} & \multicolumn{2}{|c|}{ Nilai \% } \\
\hline & & & & Siklus I & Siklus II \\
\hline 1. & Guru 1 & Kelas I & & 75 & 90 \\
\hline 2. & Guru 2 & Kelas I & & 73 & 93 \\
\hline 3. & Guru 3 & Kelas II & & 90 & 93 \\
\hline 4. & Guru 4 & Kelas II & & 80 & 88 \\
\hline 5. & Guru 5 & Kelas III & & 90 & 93 \\
\hline 6. & Guru 6 & Kelas III & & 88 & 90 \\
\hline 7. & Guru 7 & Kelas IV & Media Alat dan & 80 & 88 \\
\hline 8. & Guru 8 & Kelas IV & Sumber & 90 & 93 \\
\hline 9. & Guru 9 & Kelas V & Pembelajaran & 90 & 93 \\
\hline 10 & Guru 10 & Kelas V & & 93 & 93 \\
\hline 11 & Guru 11 & Kelas VI & & 83 & 88 \\
\hline 12 & Guru 12 & Agama & & 77 & 83 \\
\hline 13 & Guru 13 & Agama & & 88 & 90 \\
\hline 14 & Guru 14 & Penjasorkes & & 90 & 93 \\
\hline 15 & Guru 15 & Penjasorkes & & 93 & 93 \\
\hline \multirow{2}{*}{\multicolumn{3}{|c|}{$\begin{array}{l}\text { Rata-rata } \\
\text { Kualifikasi }\end{array}$}} & & 85.3 & 90.7 \\
\hline & & & & Baik & Amat \\
\hline
\end{tabular}


Berdasarkan table 10 di atas, dapat kita ketahui bahwa kompetensi guru dalam merumuskan media alat dan sumber pembelajaran pada RPP yang mereka buat telah berada pada kualifikasi baik dan amat baik. Peningkatan ini dibuktikan oleh rata-rata guru pada siklus I mendapat nilai sebesar 85.3 dan pada siklus II mendapat nilai 90.7. Untuk penilaian/ evaluasi pada siklus I dan II dapat dilihat pada table $11 \mathrm{di}$ bawah ini:

Tabel 11. Hasil Penilaian Komptensi Guru dalam Menyusun RPP melalui Kegiatan Workshop pada Siklus I dan II

\begin{tabular}{clcccc}
\hline No & Nama guru & $\begin{array}{c}\text { Mengajar kelas/ } \\
\text { Mata Pelajaran }\end{array}$ & $\begin{array}{c}\text { Indikator yang } \\
\text { Dinilai }\end{array}$ & \multicolumn{2}{c}{ Nilai \% } \\
& & Siklus I & Siklus II \\
\hline 1. & Guru 1 & Kelas I & & 75 & 77 \\
2. & Guru 2 & Kelas I & & 83 & 88 \\
3. & Guru 3 & Kelas II & & 77 & 70 \\
4. & Guru 4 & Kelas II & & 70 & 75 \\
5. & Guru 5 & Kelas III & & 73 & 75 \\
6. & Guru 6 & Kelas III & & 70 & 80 \\
7. & Guru 7 & Kelas IV & Penilaian/ Evaluasi & 75 & 88 \\
8. & Guru 8 & Kelas IV & 88 & 83 \\
9. & Guru 9 & Kelas V & & 80 & 88 \\
10 & Guru 10 & Kelas V & & 90 & 93 \\
11 & Guru 11 & Kelas VI & & 88 & 90 \\
12 & Guru 12 & Agama & & 80 & 88 \\
13 & Guru 13 & Agama & & 70 & 93 \\
14 & Guru 14 & Penjasorkes & & 78.6 & 83.6 \\
15 & Guru 15 & Penjasorkes & & Baik & Baik \\
\multicolumn{2}{r}{} & Rata-rata & & & \\
\hline
\end{tabular}

Berdasarkan table 11 di atas, dapat kita ketahui bahwa kompetensi guru dalam merumuskan penilaian/ evaluasi pembelajaran pada RPP yang mereka buat telah berada pada

\section{Pembahasan}

Berdasarkan hasil penelitian yang telah dipaparkan pada bagian sebelumnya, maka dapat disimpulkan bahwa terjadi peningkatan respon guru dalam kegiatan workshop tentang penyususnan RPP bagi guru-guru di SDN 017 Candirejo. Di samping itu juga, terjadi peningkatan kompetensi guru dalam menyusun kualifikasi baik. Peningkatan ini dibuktikan oleh rata-rata guru pada siklus I mendapat nilai sebesar 78.6 dan pada siklus II mendapat nilai 83.6.

RPP melalui workshop di SDN 017 Candirejo dari siklus I ke siklus II pada masing-masing aspek dengan target ketercapaian sesuai dengan kriteria yang ditetapkan. Peningkatan kompetensi guru sebelum tindakan workshop ke siklus I dan siklus II dapat dilihat pada tabel di bawah ini: 
Tabel 4. Rekapitulasi Hasil Penilaian Komptensi Guru Sebelum dan Sesudah Tindakan Kegiatan Workshop pada Siklus I dan II

\begin{tabular}{lcccccc}
\hline \multicolumn{1}{c}{ Indikator yang Dinilai } & $\begin{array}{c}\text { Nilai } \\
\mathbf{\%}\end{array}$ & Kualifikasi & $\begin{array}{c}\text { Nilai } \\
\mathbf{\%}\end{array}$ & Kualifikasi & $\begin{array}{c}\text { Nilai } \\
\mathbf{\%}\end{array}$ & Kualifikasi \\
\hline Kompetensi Inti & 86.3 & Baik & 87.9 & Amat Baik & 90.1 & Amat Baik \\
$\begin{array}{l}\text { Kompetensi Dasar dan Indikator } \\
\text { Tujuan Pembelajaran }\end{array}$ & 81.6 & Baik & 84.6 & Baik & 87.8 & Amat Baik \\
$\begin{array}{l}\text { Materi dan Metode Pembelajaran } \\
\text { Langkah-Langkah Pembelajaran/ }\end{array}$ & 67.6 & Cukup & 73.2 & Baik & 83.8 & Baik \\
$\begin{array}{l}\text { Kegiatan pembelajaran } \\
\text { Media Alat dan Sumber }\end{array}$ & 70.8 & Cukup & 80.8 & Baik & 89.6 & Amat Baik \\
$\begin{array}{l}\text { Pembelajaran } \\
\text { Penilaian/ Evaluasi }\end{array}$ & 72.8 & Cukup & 76.7 & Baik & 81.8 & Baik \\
$\quad \begin{array}{c}\text { Rata-rata } \\
\text { Peningkatan }\end{array}$ & 73.1 & Cukup & 78.6 & Baik & 90.7 & Amat Baik \\
& 74.4 & Cukup & 81 & Baik & 83.6 & Baik \\
& & $6.6 \%$ & & & $12.3 \%$ & Amat Baik \\
\hline
\end{tabular}

Berdasarkan tabel di atas terjadi peningkatan kompetensi guru dalam menyusun RPP tiap siklus pada setiap komponen penilaian. Peningkatan pada data sebelum dilakukan tindakan workshop dan setelah pemberian tindakan workshop pada siklus I meningkat sebesar $6.6 \%$ dan pada data sebelum tindakan ke siklus II mengalami peningkatan sebesar $12.3 \%$. Hal ini membuktikan bahwa upaya meningkatkan kompetensi guru dalam menyusun rencana pelaksanaan pembelajaran (RPP) melalui workshop di SD Negeri 017 Candirejo Kec. Pasir

\section{SIMPULAN DAN REKOMENDASI}

Berdasarkan hasil Penelitian di atas, dapat disimpulkan bahwa pelaksanaan kegiatan workshop dapat meningkatkan kompetensi guru dalam menyusun RPP di SDN 017 Candirejo Kec. Pasir Penyu. Peningkatan ini dibuktikan oleh data penilaian sebelum pemberiat tindakan rata-rata guru mendapat nilai sebesar 74.4 dengan kualifikasi cukup, setelah dilakukan tindakan pada siklus I rata-rata guru mendapat nilai sebesar 81 dengan kualifikasi baik, dan pada siklus II ratarata penilaian guru meningkat menjadi 86.7 dengan kualifikasi amat baik. Peningkatan secara persentase dari sebelum tindakan ke siklus I sebesar $6.6 \%$ dan sebelum tindakan ke siklus II
Penyu berhasil dilakukan.

Hasil penelitian ini sejalan dengan pendapat Hendriyani (2017) dan Marhan (2017) yang mengungkapkan bahwa betapa pentingnya kegiatan workshop, pelatihan, seminar dalam meningkatkan kompetensi guru. Hal ini dapat dilakukan dengan cara mengirim guru untuk mengikuti kegiatan tersebut dalam rangka menambah pengetahuan dan wawasan guru yang akan bermuara pada peningkatan kompetensi yang dimiliki guru tersebut.

sebesar $12.3 \%$.

Berdasarkan simpulan penelitian di atas peneliti menyampaikan beberapa saran sebagai berikut: 1) Untuk Penyelenggaraan workshop harus di laksanakan dengan sebaik mungkin agar guru dapat meningkatkan kompetensi yang dimilikinya dan jika perlu mengundang pemateri yang ahli dibidangnya seperti pengawas sekolah; 2) untuk peneliti lain, penelitian ini bisa dijadikan acuan dalam penelitian selanjutnya dalam cakupan kelas dan sekolah yang lebih luas agar dapat memetakan keefektifan pelaksanaan workshop terhadap peningkatan kompetensi guru, terutama dalam menyusun RPP. 


\section{DAFTAR PUSTAKA}

Baharuddin. (2019). Meningkatkan Kompetensi Guru dalam Memilih Model Pembelajaran melalui Kegiatan Suvervisi Akademik di SD Negeri 004 Dusun Tua Kecamatan Kelayang Kabupaten Indragiri Hulu. Jurnal PAJAR (Pendidikan dan Pengajaran), 3 (1), 53-60.

Gusmarni. (2019). Meningkatkan Kompetensi Guru dalam Menyusun Butir Soal melalui Kegiatan Workshop di Sekolah Dasar. Jurnal PAJAR (Pendidikan dan Pengajaran), 3(5), 1129-1136.

Hendriyani. (2017). Manajemen Kompetensi Pedagogik Guru Sekolah Menengah Atas Negeri 1 Kabawetan dalam Proses Pembelajaran. An-Nizom: Jurnal Penelitian Pendidikan Islam, 2(3), 522-528.

Kemendiknas. (2002). Keputusan Menteri Pendidikan Nasional Republik Indonesia Nomor 045/U/2002.

Maimunah. (2019). Analisis Kompetensi Profesional Guru Sekolah Dasar Negeri 001
Sungai Pinang. Jurnal PAJAR (Pendidikan dan Pengajaran), 3(6), 1239-1246.

Marhan. (2017). Upaya Kepala Sekolah dalam Meningkatkan Kinerja Guru Pendidikan Agama Islam (PAI) Di SMA Negeri 4 Pagaralam. An-Nizom: Jurnal Penelitian Pendidikan Islam, 2(1), 125-138.

Rambe, M. (2019). Pelaksanaan Supervisi Akademik Sebagai Upaya untuk Meningkatkan Kompetensi Guru dalam Menyusun Rencana Pelaksanaan Pembelajaran. Jurnal PAJAR (Pendidikan dan Pengajaran), 3(4), 782-790.

Rinawati. (2019). Upaya Peningkatkan Kemampuan Guru dalam Penggunaan Teknologi Informasi dan Komunikasi (TIK) melalui Kegiatan Workshop di TK Kecamatan Sungai Lalak. Jurnal PAJAR (Pendidikan dan Pengajaran), 3(4), 800807. 